\title{
The Impact of Foreign Direct Investment and Trade Liberalization on Economic Growth, Income Distribution and Environmental Quality: The Comparative Analysis between France and South Korea
}

\author{
${ }^{1}$ Abdul Rahim Ridzuan*, ${ }^{2}$ Nor Asmat Ismail, ${ }^{3}$ Abdul Fatah Che \\ Hamat, ${ }^{4}$ Mohamad Idham Md Razak, ${ }^{5}$ Faridah Pardi \\ ${ }^{1}$ Faculty of Business and Management, Universiti Teknologi MARA, Melaka City Campus, \\ Malaysia \\ Email: rahim670@staf.uitm.edu.my \\ ${ }^{2,3}$ School of Social Science, Universiti Sains Malaysia, Penang, Malaysia \\ Email: norasmat@usm.my, abdfatah@usm.my \\ ${ }^{4,5}$ Faculty of Business and Management, Universiti Teknologi MARA, Alor Gajah Melaka, \\ Malaysia \\ Email: iedham@melaka.uitm.edu.my, Faridah405@melaka.uitm.edu.my
}

DOI: 10.6007/IJARBSS/v7-i6/2953 URL: http://dx.doi.org/10.6007/IJARBSS/v7-i6/2953

\begin{abstract}
The main objective of this paper is to analyze the impacts of foreign direct investment (FDI) and trade openness (TO) on three main pillars of sustainable development (SD) consists of growth, income distribution, and environmental quality, for two selected countries which are South Korea and France. The observation of this study is based on annual data covering the period from 1980 to 2014. All the three proposed model are analyzed by using Autoregressive Distributed Lag (ARDL) estimation technique.The long run elasticities of ARDL model indicated that FDI inflows have led to higher growth and lower pollution level for South Korea, but have widened the income inequality in this country. The TO, on the other hand, has improved the income distribution but failed to have any significant effect on growth and environmental quality. As for France, FDI inflows were found to reduce income equality but have no significant impact on growth and environmental quality. As for TO, it was found to have a positive influence on growth. South Korea could offer more attractive incentives to foreign investors to invest more in both agricultural and manufacturing sectors besides improving the trade policies in order to sustain economic growth. France on the other hand, should be more selective especially allowing foreign industries that use cleaner energy in their production. Besides, France could adopt stricter environmental strategies in their trade agreements with other countries in order to ensure better protection for the environment.
\end{abstract}

* Corresponding author 
Keywords: Sustainable development, Foreign direct investment, Trade openness, Income inequality, Environmental Quality

\section{Introduction}

Sustainable development (SD) has become one of the most important long-term goals set by many countries around the world. The earlier concept of development which only refer to economic growth is no longer relevant. According to Brundtland report by World Commission on Environment and Development (WCED) (1987), SD is defined as "the development that meets the needs of the present without compromising the ability of future generations to meet their own needs". Since the Brundtland report, an approach call three-pillar approach to SD has emerged. This approach views SD as referring wholly to economic (economic growth), social (income distribution) and environment (environmental quality), all of which must be simultaneously sustainable because each of the three pillars is independently crucial and interconnected. A failure to reach any pillar of SD would bring unfavorable impacts to the country in the future. Thus, it is important to find potential drivers that could promote or lead the country towards the direction of SD. The concern for SD has intensified with the liberalization of trade and investment between countries where the process of business decision-making, production processes, and markets demonstrate traits that are more akin to be global than local. FDI inflows, and TO, have been promoted by various international organizations such as United Nations Conference on Trade and Development (UNCTAD) and Organization for Economic Cooperation and Development (OECD) as potential drivers for SD.

In this research paper, we intend to investigate whether FDI and/or TO will led towards SD in two economies, namely, France and South Korea, as these two countries have different strengths in terms of FDI acquisition or scope of trade liberalization. To understand further, the trend of FDI inflows as percentage of GDP as well as the trend of TO between these two countries are presented in the Figure 1 and Figure 2. The trends of FDI and TO for France and South Korea are given in Figure 1 and Figure 2, respectively, as below:

FDI inflows (\% of GDP)

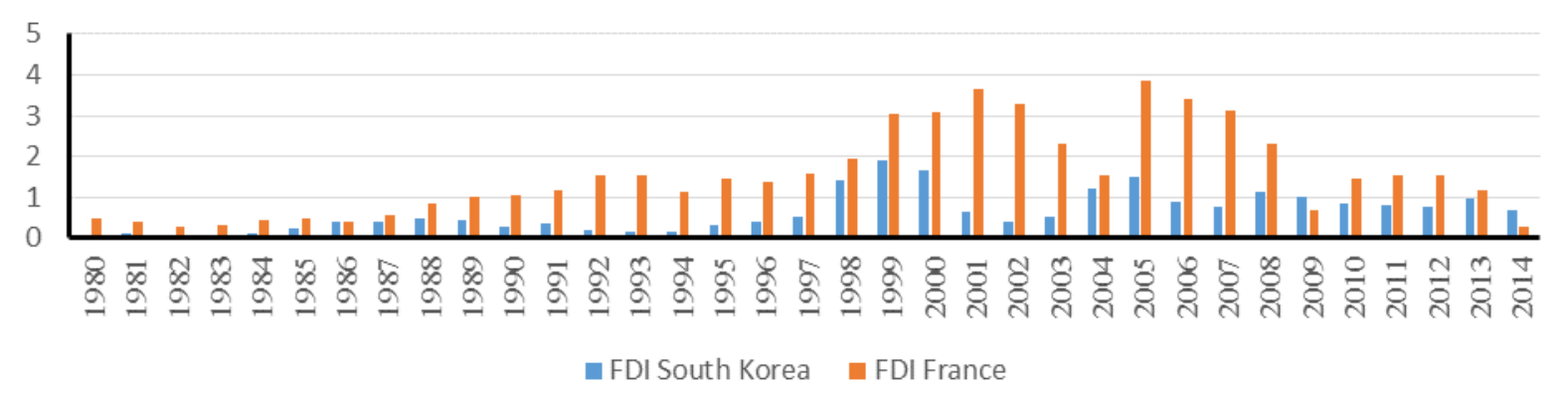

Figure 1: The trend of FDI inflows (\% of GDP) for France and South Korea from 1980 until 2014 (year)

France is considered as one of the top ten economic power. As a nation that sits strategically in the center of Europe, this country prides itself as an innovative country, accompanied by its developed tertiary economic sector. Paris is housed as the world second host to multinational headquarters, only proceeded by Tokyo. France has provided an easy passage for foreign investor to conduct investment and also practices flexible and stable legal environment for business to flourish. Overall, the FDI inflows as \% of GDP in France is 
really outstanding where the upward trend can be seen clearly from early 1980s until 2001. However, from 2002 onwards, the flows has decreased from $3.30 \%$ in 2002 to $1.54 \%$ in 2004 due to the economic slowdown, before it increased back to $3.86 \%$ in 2005 due to the economic slowdown. The FDI inflows into France went into contraction phase from 2006 until 2014. The FDI inflows in France hits its lowest point in 2014 after experiencing three years of decline. Compared to France, total FDI inflows as \% of GDP in South Korea is relatively lower. However, the trend of FDI inflows in this country is more stable. South Korea's appeal in terms of FDI is the result of the country's rapid economic development and the specialization in new information and communication technologies. Japan, USA, and Netherland are the top three contributors to FDI inflows into South Korea. The lack of general transparency in regulations is a major concern to foreign investors. South Korea currently ranks seventh among the most attractive countries in South and East Asia for transnational companies. FDI flows into South Korea had been more or less constant in recent years-averaging around $1.5 \%$ of GDP-but they are declining due to external shocks, including the recent unfavorable economic disturbance around the world.

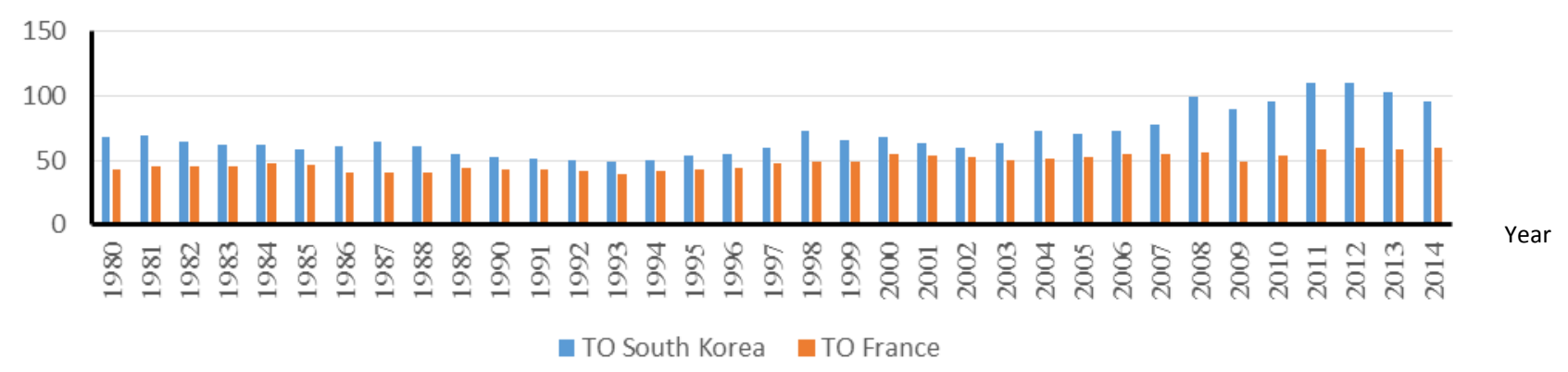

\section{Figure 2: The trend of Trade Openness for France and South Korea from 1980 until 2014}

Figure 2 above shows the trend of openness to trade for France and South Korea. Based on this diagram, South Korea's TO is relatively higher as compared to France. The TO for South Korea is showing an upward trend while the TO for France is more constant from 1980 to 2014. Historically, France was known as a country that leads in the fights against globalization, of which, the rising of free trade agreements (FTAs) being part of it. This country is prone to highlight the negative side effects of globalization and as a result, has rejected the concept of globalization. However, over time, this country has slowly adapted both trade liberalization and market liberalism, as a result of European integration. As compared to South Korea, trade has been the driving force for this country's economic growth since 1960s and it's TO is still expanding, through active participation in bilateral and multilateral free trade agreements with other countries. As for South Korea, there is no doubt about the economy's close relation with the trade. Based on the figures above, it can be seen that South Korea has achieved its highest TO of 110 points in 2011, while France recorded its highest point of only 59 points in 2014.

To summarize, as France and South Korea are located in two different continents, it is expected that these countries would exhibit different patterns of investment and trade, due to the differences in the countries' surroundings and environment, involvement in regional economic integration, and others. This explains why France has received, a higher 
volume of FDI inflows which mainly comes from other European countries, probably due to the country's membership in the European Union (EU), while South Korea on the other hand, has recorded higher amount of trade as this country relies on trade as the main driving force of the economy. It is for the differences such as these, that exist between France and South Korea, that prompt us to investigates the effects of FDI inflows and TO on the three pillars of SD in order to determine whether they (FDI inflows and TO) have impacts on SD in these countries or not. The comprehensive views for evidence of SD based on three different econometric models build upon the three pillars of SD offered in this study would be a new contribution offered in this research paper.

The rest of the paper is structured as follows: Section 2 presents the literature review, Section 3 describes the methodology, while Section 4 will focus on empirical analysis. Section 5 concludes the paper.

\section{Literature Review}

In this section, the review of the literature was limited to papers that included FDI inflows, and TO in a singular framework. First, based on the model of growth, Klasra (2011) has analyzed the relationship between FDI and TO on growth for Pakistan and Turkey using Bound estimation also known as ARDL, with annual data from 1975 to 2004. The long run elasticities showed that both TO and export have a positive impact on Pakistan economic growth. Meanwhile, FDI is not significant and thus failed to explained growth. As for Turkey, export is the only determinant that has a positive and significant relationship with growth. Next, Belloumi (2014) tested the relationship between trade, FDI and economic growth in Tunisia using ARDL estimation technique. The period of study was from 1970 to 2008 . The estimated coefficients of the long run relationship are significant for capital investment and labor but not significant for TO and output per capita. Capital investment has a positive and significant impact on FDI at 5 per cent level. The labor force, on the other hand, is negative and significant at 5 percent level. This indicates a growing unemployment problem and low productivity of labor in Tunisia, which demotivated the foreign investors from investing in this country. A more recent study conducted by Solarin and Shahbaz (2015), by using ARDL estimation has found that that natural gas consumption, FDI, capital and TO have a positive relationship with economic growth for Malaysia.

Based on the model of income distribution, Celik, and Basdas (2010) examined how income distribution is affected by the FDI inflows, FDI outflows and TO of a country. The authors grouped the tested countries into three groups consisting of developing countries (Argentina, Brazil, Czech Republic, Hungary, and Polland), developed countries (France, Germany, Netherland, UK and U.S) and miracle countries (China, India, Korea, Malaysia, Singapore, and Thailand). The authors used panel Full Modified-Ordinary Least Square (OLS) estimation to run the analysis. Based on the results for developing countries, it is shown that FDI inflows contribute to income equality, while TO has a deteriorating effect on income equality. The results for the developed countries also shows a negative relationship between FDI inflows as well as outflows with GINI coefficients, supporting the view that creation of employment and the increase in the tax revenue enhances the strength of the social state contribution to income distribution. The TO also exhibit a negative relationship with GINI coefficients, reflecting the division of labor and marginal productivity for the labor. As for 
miracle countries, FDI inflows have worsened the income equality given that these countries often repress the wages of less skilled labor in order to attract more FDI. On the other hand, the outcome of TO on GINI coefficient is similar with other two groups of countries, implying increasing chance of more welfare for the whole society (Sato and Fukushige, 2009). Next, Mushtaq et al., (2014) tested the impact of FDI inflows on income distribution in Bangladesh, India, Nepal, Pakistan, and Siri Lanka using panel data from 1980 to 2011. The study found that both FDI inflows and inflation have a negative and significant relationships with GINI coefficients, implying that FDI has improved the income distribution. The increase of TO and per capita GDP, on the other hand, have worsened the income distribution in these countries.

Based on the environmental quality model, Shahbaz et al. (2013) has analyzed the impact of incomes, energy consumption, TO, FDI inflows and financial development (FD) on $\mathrm{CO}_{2}$ emissions for Malaysia over the period from 1971 to 2011, by using the Bound estimation technique. The outcome of the analysis revealed that higher FD has reduced $\mathrm{CO}_{2}$ emissions. While energy consumption, FDI inflows, and economic growth have worsened the air quality. Laslty, Abdouli, and Hammami (2016) has adopted several panel estimation techniques comprising both static [OLS, Fixed Effects (FE), Random Effects (RE)] and dynamic [difference Generalized Method of Moments (GMM) and system GMM] to investigate the impact economic growth, FDI inflows, TO and energy consumption on environmental quality in 17 selected Middle East and North Africa (MENA) countries. The study also tested the validity of Environmental Kuznets Curve (EKC) hypothesis in these countries. The overall findings of the static panel tests based on FE showed that environmental quality of MENA countries is very sensitive to the level of economic growth, FDI inflows, TO, and energy consumption. On the other hand, the results from the system GMM tests showed that environmental quality is not sensitive to the level of TO. The validity of EKC hypotheses validity is confirmed by both tests where the square of GDP was found to have a negative relationship with $\mathrm{CO}_{2}$ emissions.

To summarize, we can conclude from the empirical findings above that the impact of FDI inflows and TO in a singular framework are mixed. The review also highlights the fact that the studies involving the impact of both FDI inflows and TO on the three pillars of SD was very limited and to the best of our knowledge, no test was ever carried out for the case of France and South Korea. Thus, it is hoped that the outcome of this research paper can close the literature gap in this area and enrich the body of knowledge on the topics of SD, in general.

\section{Methodology}

The formulation of the three econometric models representing the three pillars of SD is explained briefly in this section. All expected sign are carefully explained to give a deeper understanding on the relationship between each independent variable on dependent variable. The proxy of the variables from the three models introduced in this study are same. All variables were transformed into log-linear form to translate the result into long run elasticities.

\section{Model of Economic Growth}


The proposed model of economic growth is basically based on the Cobb-Douglas production function that was extended with relevant variables as introduced in this study to avoid omitted variables problem. The model can be seen as follows:

$$
L N G D P_{t}=\delta_{0}+\gamma_{1} L N L A B_{t}+\gamma_{2} L N D I_{t}+\gamma_{3} L N F D I_{t}+\gamma_{4} L N H C_{t}+\gamma_{5} L N T O_{t}+\gamma_{6} L N F D_{t}+\mu_{t_{t}} \ldots(1)
$$

where GDP is real gross domestic product per capita (2005), LAB is total labor force, DI is domestic investment proxied by the ratio of fixed capital formation to GDP, FDI is foreign direct investment inflows to GDP, HC is human capital proxied by secondary school enrollment rate, TO is trade openness measured by the sum of export and import to GDP and FD is financial development proxied by money supply, M2 to GDP. In the case of developed countries who are capital abundance such as France and South Korea, LAB is expected to have a positive relationship with GDP with the assumption that the labor does not yet fully utilized the available capital. The expected sign for DI might be either positive or negative. It will have a positive sign if DI makes a larger proportion of domestic capital, while it has a negative sign if accretions of foreign capital do not complement with private capital formation. FDI also is expected to have either positive or negative relationship with GDP. According to dependency hypothesis as introduced by Frank (1978), FDI could lead towards decapitalization if FDI diverts capital towards areas of FDI activity from other more productive areas. Meanwhile, according to modernization hypothesis as introduced by Rostow (1960), FDI could lead towards higher economic growth as economic growth requires capital investment. $\mathrm{HC}$ is expected to have a positive impact on GDP. This is because, $\mathrm{HC}$ is importance for absorbing foreign knowledge that enter into the country in the form of technology. Similar to HC, TO also is expected to have positive relationship with GDP. According to Krueger (1978), the TO promotes growth since it can enhances specialization and division of labor in the production of goods and services. Bhagwati hypothesis added that the impact of FDI on economic growth tends to be greater under the country who adopted an export promotion trade stratergy than to an import substitution stratergy. Lastly, the addition of FD could act as a control variable in the model. It is expected that FD have a positive relationship with GDP given that a well fucntioning and efficient financial markets could reduce the risks inherent in the investment (Shahbaz et. al 2010), besides provides better allocation of resources, better monitoring, more information symmetry, and higher economic growth (Levine, 1997).

\section{Model of Income Distribution}

The origin of income distribution model introduced in this study was basically came from Mah (2003), who stated that globalization is characterized by higher FDI inflows and higher degree of TO. The author believed that foreign investment and TO could raised up the wage rate in developing countries and thus influenced the income distribution in the countries. We make some modification by including additional important variables into the model which is shown as follows:

$$
\text { LNGINI }_{t}=\delta_{0}+\eta_{1} L N G D P_{t}+\eta_{2} L N D I_{t}+\eta_{3} L N F D I+\eta_{4} L N T O_{t}+\eta_{5} L N F D+\mu_{t} \ldots \text { (2) }
$$

where GINI is Gini coefficient, GDP is gross domestic per capita, DI is domestic investment, FDI is foreign direct investment inflows, TO is trade openness and FD is financial development. GDP is expected to have either positive or negative relationship with GINI. If it is a positive sign, it shows that the development achived by the country was not sustainable as there is an increase in income disparity within the society, while a negative sign show that the country development was consistent with the increases of income distribution. Similar 
to GDP, the expected sign for DI is also positive or negative. According to Neoclassical theorist, a negative relationship between DI and GINI could be explained by the intuition that increases in DI spending mean more people getting jobs, earning more and thus putting a downward pressure in income inequality. FDI could have a positive or negative relationship with GINI. According to Sylwester (2005), as a results of higher FDI inflows, it will lead towards higher demand for unskilled workers and thus raising their earnings and improve the income inequality. This situasion is valid for the case of developing countries. However, the reverse processess take place in the developed country. Next, TO is expected to have a positive relationship as suggested by Dependency theorist. As for FD, it is expected to have a negative relationship with Gini. According to Canavire-Bacarreza and Rioja (2009), easy access to financial resources the society enable them to make a loan in education, became a graduates with higher chances of employment and better salaries, hence reduce income inequality.

\section{Model of Environmental Quality}

For the third pillar of SD namely environmental quality, we make some modification on the model introduced by Lee (2013) which is listed as follows:

$$
L N C O_{2 t}=\delta_{0}+\chi_{1} L N G D P_{t}+\chi_{2} L N E N Y_{t}+\chi_{3} L N P O P+\chi_{4} L N F D I_{t}+\chi_{5} L N T O+\chi_{6} L N F D+\mu_{t} \ldots(3)
$$

where $\mathrm{CO}_{2}$ is carbon dioxide in metric ton per capita representing environmental quality, ENY is energy consumption in $\mathrm{kg}$ of oil equivalent and POP is the total population. The remaining variables (GDP, FDI, FD and TO) are similar to the variables that we used in the previous two models. GDP is expected to have a negative relationship with $\mathrm{CO}_{2}$ emissions for both France and South Korea. As the country reached at certain level of development, the release of $\mathrm{CO} 2$ emissions is become lesser as a results of cleaner technology adopted by the country. ENY could have either both positive or negative sign with $\mathrm{CO}_{2}$ emissions depending on what types of energy used by the industries in the country. If the country still depend on coal as a source of energy, it will exhibit positive sign. However, it could be a negative sign if the countries adopt efficient consumption of energy. Next, POP is expected to have a positive relationship with $\mathrm{CO}_{2}$ emissions. Higher amount of population in the country could lead towards demand for a goods and services and thus increasing the industrial activities which results in higher release of $\mathrm{CO}_{2}$ emissions. Meanwhile, $\mathrm{FDI}$ is expected to have either positive of negative relationship with $\mathrm{CO}_{2}$ emissions. FDI may contribute to the linkages between $\mathrm{CO}_{2}$ emissions and economic performance via two channel. First, FDI may lead to an increase in national output, and thus lead to a positive impact on $\mathrm{CO}_{2}$ emissions. Second, more efficient production technology may take place as a result of FDI and thus improve the environmental quality (Stretesky and Lynch, 2008). Similar to FDI, TO also have either positive or negative impacts on $\mathrm{CO}_{2}$ emissions. For negative sign, an increase in TO could increase the import of the environmental friendly and more efficient technologies. As for positive sign, an increase in export of domestic products were likely to increase the environmental degradation. Lastly, the negative relationship between $\mathrm{FD}$ and $\mathrm{CO}_{2}$ emissions can take place when financial development in the countries allocates some financial resources to firms to utilize environment- friendly technology which uses energy efficient and emits fewer carbon emissions (Tamazian \& Rao, 2010). However, financial development may harm environment which represents a positive relationship by increasing $\mathrm{CO}_{2}$ emissions through the growth of industrial sector. 
The Unrestricted Error Correction Model (UECM) Bound form for all three proposed model that consist both short run and long run dynamics is shown as follows:

$$
\begin{aligned}
& \Delta L N G D P_{t}=\beta_{0}+\theta_{0} L N G D P_{t-1}+\theta_{1} L N L A B_{t-1}+\theta_{2} L N D I_{t-1}+\theta_{3} L N F D I_{t-1}+\theta_{4} L N H C_{t-1}+\theta_{5} L N T O_{t-1}+\theta_{6} L N F D_{t-1} \\
& +\sum_{i=1}^{p} \beta_{i} \Delta L N G D P_{t-i}+\sum_{i=0}^{q} \rho_{i} \Delta L N L A B_{t-i}+\sum_{i=0}^{r} \delta_{i} \Delta L N D I_{t-i}+\sum_{i=0}^{s} \lambda_{t-i} \Delta L N F D I_{t-i}+\sum_{i=0}^{t} \vartheta_{t-i} \Delta L N H C_{t-i}+\sum_{i=0}^{u} \zeta_{t-i} \Delta L N T O_{t-i} \\
& +\sum_{i=0}^{v} \psi_{t-i} \Delta L N F D_{t-i}+v_{t} \ldots(4)
\end{aligned}
$$$$
\Delta L N G I N I_{t}=\beta_{0}+\theta_{0} L_{N G I N I_{t-1}}+\theta_{1} L_{N G D P_{t-1}}+\theta_{2} L N D I_{t-1}+\theta_{3} L_{N F D I_{t-1}}+\theta_{4} L N T O_{t-1}+\theta_{5} L N F D_{t-1}+\sum_{i=1}^{p} \beta_{i} \Delta L N G I N I_{t-i}
$$$$
+\sum_{i=0}^{q} \rho_{i} \Delta L N G D P_{t-i}+\sum_{i=0}^{r} \delta_{i} \Delta L N D I_{t-i}+\sum_{i=0}^{s} \lambda_{t-i} \Delta L N F D I_{t-i}+\sum_{i=0}^{t} \vartheta_{t-i} \Delta L N T O_{t-i}+\sum_{i=0}^{u} \zeta_{t-i} \Delta L N F D_{t-i}+v_{t} \ldots(5)
$$

$$
\begin{aligned}
& \Delta L N C O_{2 t}=\beta_{0}+\theta_{0} L N C O_{2 t-1}+\theta_{1} L N G D P_{t-1}+\theta_{2} L N E N Y_{t-1}+\theta_{3} L_{N P O P_{t-1}}+\theta_{4} L N F D I_{t-1}+\theta_{5} L N T O_{t-1}+\theta_{6} L N F D+ \\
& \sum_{i=1}^{p} \beta_{i} \Delta L N C O_{2 t-i}+\sum_{i=0}^{q} \rho_{i} \Delta L N G D P_{t-i}+\sum_{i=0}^{r} \delta_{i} \Delta E N Y_{t-i}+\sum_{i=0}^{s} \lambda_{t-i} \Delta L N P O P_{t-i}+\sum_{i=0}^{t} \vartheta_{t-i} \Delta L N F D I_{t-i}+\sum_{i=0}^{u} \zeta_{t-i} \Delta L N T O_{t-i} \\
& +\sum_{i=0}^{v} \psi_{t-i} \Delta L N F D+v_{t} \ldots(6)
\end{aligned}
$$

where $\Delta$ is the first difference operator and $u_{t}$ is the white-noise disturbance term. This study used annual data starting from 1980 to 2014. The data POP, CO2, DI, EN, FD, FDI, GDP, LAB, and TO are taken from World Development Indicator, (WDI) (2016), while the HC data is taken from Barro and Lee (2011) database. The completion of the data is done in the following ways: The LAB is completed by using data from International Labor Organization (ILO) (2015); $\mathrm{CO}_{2}$ emissions by using Emissions Database for Global Atmospheric Research (EDGAR) 2015; and GINI data is completed by using sources from Global Consumption Income Project (GCIP) (2015).

\section{Empirical Analysis}

The analysis began by testing the stationarities of the data by performing unit root tests such as Augmented Dickey-Fuller (ADF) and Phillip-Perron (PP). Given a naturality of the data used in this study, we found that there is a mix of stationarities at I (0) and I (1) for the variables used in each model for both countries. This allowed us to proceed to the next analysis by using ARDL estimation technique. Table 1 shows the result of ARDL cointegration tests. The maximum lag of 4 was imposed in each model using Akaike Information criterion (AIC). The model of growth and the model of income distribution have followed critical value where $k$ is equivalent to 6 while for the model of environmental quality, it followed the second set of critical value table where the number of variables, $k$ is equivalent to 5 . As for France, the F-statistic for each model $(6.60,4.81$ and 6.32$)$ is found to be higher than the upper I (1) critical value table (for $k=6$ and 5) and significant at 1 percent level thus confirming the existence of the long run relationship. Similar results are obtained for South Korea where the F-statistics for the three proposed models (4.10, 24.93 and 5.30) are larger than upper bound critical value with the significance level of $1 \%$ and $5 \%$ level. Thus, the long-run cointegration is confirmed for all three models in this study for both countries. 
Table 1: Results of ARDL cointegration analysis

\begin{tabular}{|c|c|c|c|c|c|}
\hline Model & Max. lag & \multicolumn{2}{|c|}{ Lag order } & \multicolumn{2}{|c|}{ F Statistic } \\
\hline \multicolumn{6}{|l|}{ France } \\
\hline Model of Growth & $4(2,1)$ & \multicolumn{2}{|c|}{$(1,1,1,0,0,1,0)$} & \multicolumn{2}{|c|}{$6.608 * * *$} \\
\hline Model of Income Distribution & $4(3,3)$ & \multicolumn{2}{|c|}{$(3,3,2,2,2,3)$} & \multicolumn{2}{|c|}{$4.812 * * *$} \\
\hline $\begin{array}{l}\text { Model of Environmental } \\
\text { Quality }\end{array}$ & $4(1,3)$ & \multicolumn{2}{|c|}{$(1,3,3,2,3,1,1)$} & \multicolumn{2}{|c|}{$6.329 * * *$} \\
\hline \multicolumn{6}{|l|}{ South Korea } \\
\hline Model of Growth & $4(2,2)$ & \multicolumn{2}{|c|}{$(1,0,0,0,2,0,1)$} & \multicolumn{2}{|c|}{$4.105 * *$} \\
\hline Model of Income Distribution & $4(3,4)$ & \multicolumn{2}{|c|}{$(1,4,4,1,4,4)$} & \multicolumn{2}{|c|}{$24.934 * * *$} \\
\hline $\begin{array}{l}\text { Model of Environmental } \\
\text { Quality }\end{array}$ & $4(4,1)$ & \multicolumn{2}{|c|}{$(4,1,0,1,1,1,1)$} & \multicolumn{2}{|c|}{$5.300 * * *$} \\
\hline & & \multicolumn{2}{|c|}{$k=6$} & \multicolumn{2}{|c|}{$k=5$} \\
\hline Critical Values for F-statistics $\#$ & & $\begin{array}{c}\text { Lower I } \\
\text { (0) }\end{array}$ & Upper I (1) & $\begin{array}{l}\text { Lower I } \\
\text { (0) }\end{array}$ & $\begin{array}{c}\text { Upper I } \\
\text { (1) }\end{array}$ \\
\hline $1 \%$ & & 3.15 & 4.43 & 3.41 & 4.68 \\
\hline $5 \%$ & & 2.45 & 3.61 & 2.62 & 3.79 \\
\hline $10 \%$ & & 2.12 & 3.23 & 2.26 & 3.35 \\
\hline
\end{tabular}

Note: 1. \# The critical values are based on Narayan (2004), case III: unrestricted intercept and no trend. 2 . $\mathrm{k}$ is a number of variables $3 . *, * *$, and $* * *$ represent $10 \%, 5 \%$ and $1 \%$ levels of significance, respectively. 4 . $k=5$ for the model of income distribution and $k=6$ for the model of growth and the model of environmental quality.

The purpose of the diagnostic tests is to determine whether the long-run relationships of the variables are reliable or not. In summary, the results of the tests as displayed in Table 2 below indicate no evidence of serial correlation, no heteroscedasticity effect in the disturbances, the error terms are normally distributed and all models are well specified.

Table 2: Results of Diagnostic Checking

\begin{tabular}{lcccc}
\hline Model & $\begin{array}{c}\text { Serial } \\
\text { correlation }\end{array}$ & $\begin{array}{c}\text { Functional } \\
\text { form }\end{array}$ & Normality & Heteroscedasticity \\
\hline France & \multicolumn{5}{l}{} \\
\hline Model of Growth & 2.381 & 2.681 & 1.332 & 0.584 \\
& {$[0.114]$} & {$[0.115]$} & {$[0.513]$} & {$[0.809]$}
\end{tabular}




\begin{tabular}{lcccc}
\hline Model of Income & 2.167 & 0.281 & 0.497 & 1.459 \\
Distribution & {$[0.170]$} & {$[0.784]$} & {$[0.779]$} & {$[0.262]$} \\
Model of Environmental & 1.376 & 1.244 & 0.096 & 0.904 \\
Quality & {$[0.300]$} & {$[0.290]$} & {$[0.953]$} & {$[0.594]$} \\
\hline South Korea & & & & \\
\hline Model of Growth & 0.108 & 0.214 & 3.804 & 0.9127 \\
& {$[0.897]$} & {$[0.648]$} & {$[0.149]$} & {$[0.538]$} \\
Model of Income & 2.517 & 0.094 & 0.812 & 1.188 \\
Distribution & {$[0.284]$} & {$[0.778]$} & {$[0.666]$} & {$[0.488]$} \\
Model of Environmental & 0.853 & 0.630 & 0.686 & 0.698 \\
Quality & {$[0.448]$} & {$[0.440]$} & {$[0.709]$} & {$[0.752]$} \\
\hline
\end{tabular}

Note. 1. The numbers in brackets [ ] are p-values.

Regarding the stability of the three models, we performed another diagnostic test, namely the Sum of Recursive Residual (CUSUM) and the Cumulative Sum of Squares of Recursive Residual (CUSUM square). The graphs in Figure 3 below confirmed that all three models for France are structurally stable given that the blue line lies within the two dotted red lines. 


\section{Model of Growth}
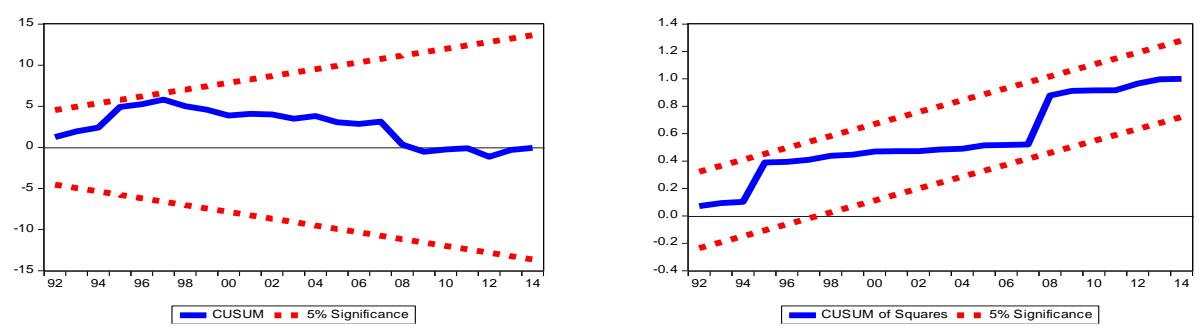

Model of Income Distribution
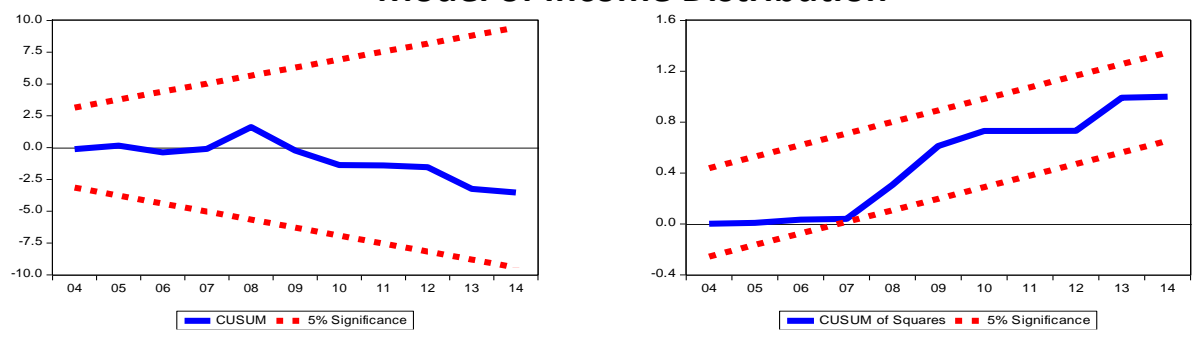

Model of Environmental Quality
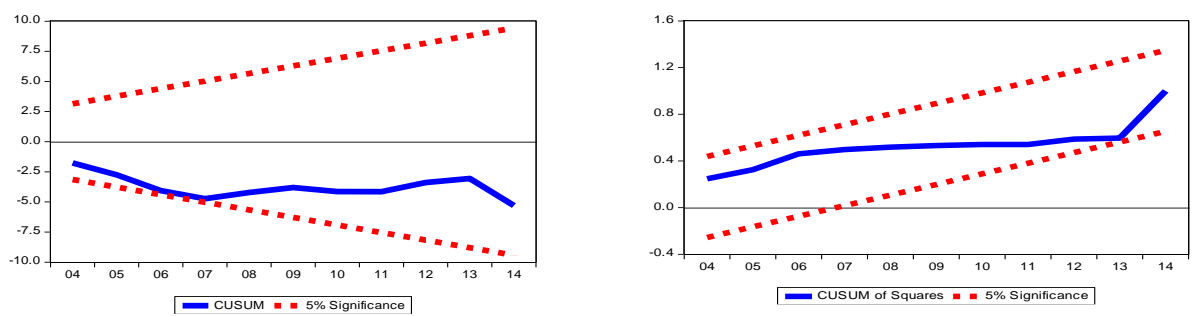

Figure 3: CUSUM and CUSUMSQ for France

Likewise, for South Korea, the CUSUM and CUSUM square results as reported in Figure 4 below, verify that each model for South Korea is structurally stable given since the blue line lie between the two dotted red lines. 
Figure 4: CUSUM and CUSUMSQ for South Korea

\section{Model of Economic Growth}
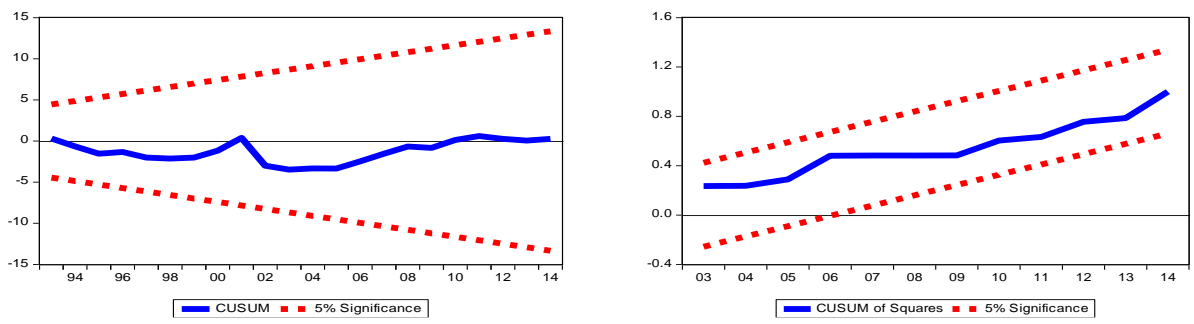

Model of Income Distribution
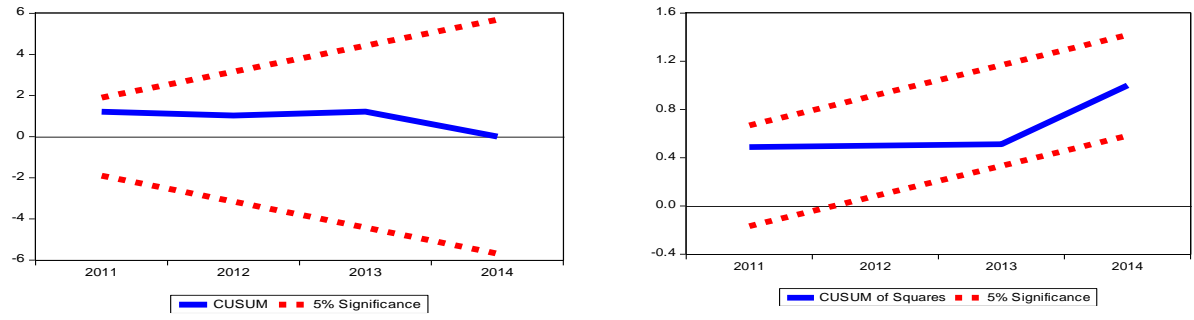

Model of Environmental Quality
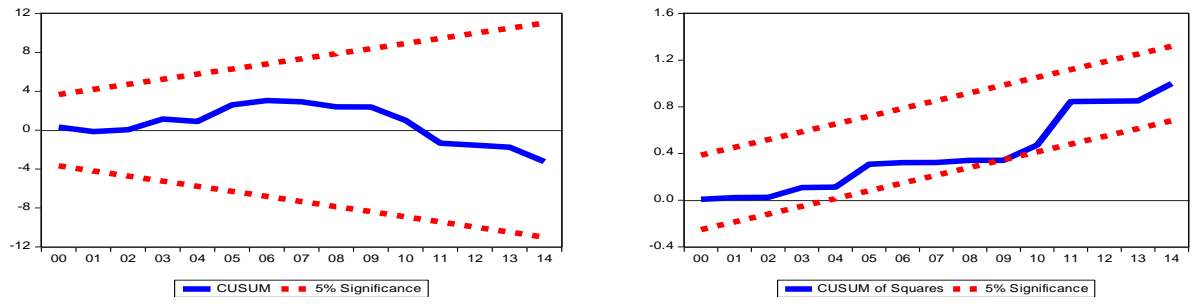

The long run elasticities for each model are displayed in Table 3a for France and Table $3 b$ for South Korea below. Based on France's model of growth, it is found that LAB, HC, and TO have a positive influence on growth. A $1 \%$ increase in $\mathrm{LAB}, \mathrm{HC}$ and TO will increase the growth by $0.91 \%, 3.10 \%$, and $0.35 \%$, respectively. FD, on the other hand, has a negative and significant relationship with the GDP. Both DI and FDI are found to be insignificant at any level and thus have no impact on South Korea's growth. Based on the model of income distribution, there are only two variables that influence the GINI coefficient. DI was found to have a negative relationship with GINI coefficient, which means that an increase in DI will reduce the GINI coefficient. Lower GINI coefficient implies better income distribution for the country. Meanwhile, FDI was found to have a positive and significant relationship with GINI. Higher FDI inflows lead to higher GINI coefficient, thus increasing income inequality in the country. This finding is in line with the previous study conducted by Wu and Shu (2012), which found that an increase in FDI inflows tends to decrease income distribution. Next, based on the results for the model of environmental quality, the sign of the coefficients for both ENY and TO are found to be positive, and significant at $5 \%$ and $10 \%$ levels. This suggests that a rise in energy 
consumption and expansion of free trade reduce environmental quality in France. Ecological economists such as Cole, Rayner and Bates (1997), have argued that TO is expected to generate negative environmental externalities especially when rich countries invest in dirty industries in host countries. Meanwhile, GDP of the country has been found to have a negative relationship with $\mathrm{CO}_{2}$ emissions. This outcome gives a glimpse of the validity of Environmental Kuznets Curve (EKC) which mean that the continued positive growth in France will eventually cause its society to demand better air quality and thus improving the overall environmental quality.

Table 3a: Estimation of Long-Run Elasticities

(France)

\begin{tabular}{cccccc}
\hline $\begin{array}{c}\text { Model of Economic Growth } \\
\text { LNGDP }\end{array}$ & \multicolumn{2}{c}{$\begin{array}{c}\text { Model of Income Distribution } \\
\text { LNGINI }\end{array}$} & \multicolumn{2}{c}{$\begin{array}{c}\text { Model of Environmental } \\
\text { Quality } \\
\text { LNCO }_{2}\end{array}$} \\
\hline Variables & Coefficient & Variables & Coefficient & Variables & Coefficient \\
\hline LNLAB & $0.914^{* * *}$ & LNGDP & -0.266 & LNGDP & $-2.114^{* * *}$ \\
LNDI & 0.051 & LNDI & $-1.855^{* *}$ & LNENY & $2.707^{* *}$ \\
LNFDI & 0.020 & LNFDI & $0.175^{*}$ & LNPOP & -0.037 \\
LNHC & $3.106^{*}$ & LNTO & 0.106 & LNFDI & 0.047 \\
LNTO & $0.353^{*}$ & LNFD & 0.100 & LNTO & $0.690^{*}$ \\
LNFD & $-0.155^{*}$ & C & $16.126^{* * *}$ & LNFD & 0.078 \\
C & $5.905^{* *}$ & & & C & -1.837 \\
\hline
\end{tabular}

Note: $1 . * * *, * *, *$ indicate significance at $1 \%, 5 \%$ and $10 \%$ levels, respectively.

Based on the results of the model of growth for South Korea in Table $4 \mathrm{~b}$ below, it is confirmed that LAB, FDI, and FD have a positive and significant impact on GDP. This positive impact of FDI and FD on growth thus validates the FDI-led growth and FD-led growth policies pursued in this country. DI and TO, on the other hand, failed to show any significant influence on GDP. Next, based on the results of the model of income distribution, DI is seen to yield better income distribution, a result which is similar to that of France. The negative relationship between DI and GINI can be explained by appealing to the intuition that increases in domestic investment spending mean more people are getting the jobs, which implies that more people are earning, thereby putting a downward pressure on income inequality. Besides, the results also show that TO and FD have improved income equality in the country. According to Arora (2012), lower income disparity is may be due to the practice of the financial sector which provides loans at a cheaper cost to farmers in order to promote rural economy and this lowers income inequality and reduces poverty. The negative relationship between TO and GINI coefficient for South Korea in this study, is consistent with Grossman and Kruger, (1995) which found that the coefficient of TO with respect to GINI coefficient is negative in developed countries. The positive impact of GDP and FDI on GINI coefficient implies that an increase in these two variables will worsen the income distribution. The finding of a positive relationship between FDI and GINI coefficient in this study differs from the findings by Mah (2003) on South 
Korea, where no significant relationship was detected between these two variables. Lastly, the results of the model of environmental quality show that rising GDP and FDI inflows have improved the environmental quality. This may reflect the fact that the MNC companies which invest in South Korea may have adopted a modern technology in their production processes and employed the best environmental practices, thus leading to higher energy efficiency. Meanwhile, the study also found that rising ENY leads to higher environmental degradation. As for as TO is concerned, the study showed that it exerts a positive but non-significant effects on South Korea's $\mathrm{CO}_{2}$ emissions.

\section{Table 3b: Estimation of Long-Run Elasticities (South Korea)}

\begin{tabular}{lclclc}
\hline \multicolumn{2}{c}{$\begin{array}{c}\text { Model of Economic Growth } \\
\text { LNGDP }\end{array}$} & \multicolumn{2}{c}{$\begin{array}{c}\text { Model of Income Distribution } \\
\text { LNGINI }\end{array}$} & \multicolumn{2}{c}{$\begin{array}{c}\text { Model of Environmental } \\
\text { Quality } \\
\text { LNCO }_{2}\end{array}$} \\
\hline Variables & Coefficient & Variables & Coefficient & Variables & Coefficient \\
\hline LNLAB & $2.630^{* * *}$ & LNGDP & $0.229^{*}$ & LNGDP & $-0.600^{* *}$ \\
LNDI & 0.045 & LNDI & $-0.847^{* *}$ & LNENY & $1.357^{* * *}$ \\
LNFDI & $0.379^{*}$ & LNFDI & $1.185^{* * *}$ & LNPOP & 0.0002 \\
LNHC & $0.041^{* *}$ & LNTO & $-0.728^{* * *}$ & LNFDI & $-0.179^{* *}$ \\
LNTO & -0.023 & LNFD & $-0.351^{* *}$ & LNTO & 0.041 \\
LNFD & $0.145^{* *}$ & C & $3.731^{* *}$ & LNFD & 0.051 \\
C & $-41.296^{* * *}$ & & & C & $-3.364^{* * *}$ \\
\hline
\end{tabular}

Note: $1 . * *, * *, *$ indicate significance at $1 \%, 5 \%$ and $10 \%$ levels, respectively.

Lastly, Table $4 \mathrm{a}$ and $4 \mathrm{~b}$ below report the results for short run elasticities and Error Correction Term (ECT). As for France, the results based on the model of growth (Table 5a), show that there are no variables in the model that have any influence in the short run. Based on the model of income distribution, it is found that both DI and FD have a negative influence on income distribution. In other words, an increase in both DI and FD will improve income distribution in France. Meanwhile, FDI was found to have a positive relationship with GINI coefficient, which means that higher FDI can widen the income disparity in this country. As for the model of environmental quality, we found that the control variable, POP has a negative influence on $\mathrm{CO}_{2}$ emissions in this country. In the case of ENY, its increase can lead to more $\mathrm{CO}_{2}$ emissions.

ECT reflects the speed of adjustment for each model and the negative value means that the variables in each model will converge in the long run. The highest speed of adjustment for France is detected from the model of income distribution (-0.58), followed by a model of environmental quality (-0.32) and model of growth (-0.12). Approximately, 58\%, 32\% and $12 \%$ disequilibria from the previous year's shock, respectively, converge back to the long run equilibrium in the current year. Overall, the R-square value for all three models suggests that almost $99 \%$ (model of growth), 89\% (model of income distribution) and $98 \%$ (model of 
environmental quality) of the variables in all three models explains the dependent variables (GDP, GINI, and $\mathrm{CO}_{2}$ ).

Table 4a: Estimation of Short Run Restricted Error Correction Model (ECM) (France)

\begin{tabular}{|c|c|c|c|c|c|}
\hline \multicolumn{2}{|c|}{$\begin{array}{c}\text { Model of Economic Growth } \\
\text { LNGDP }\end{array}$} & \multicolumn{2}{|c|}{$\begin{array}{l}\text { Model of Income Distribution } \\
\text { LNGINI }\end{array}$} & \multicolumn{2}{|c|}{$\begin{array}{l}\text { Model of Environmental Quality } \\
\qquad \mathrm{LNCO}_{2}\end{array}$} \\
\hline Variables & Coefficient & Variables & Coefficient & Variables & Coefficient \\
\hline$\Delta \mathrm{LNLAB}$ & -0.008 & $\Delta$ LNGINI $_{(-1)}$ & -0.097 & $\Delta$ LNGDP & 0.224 \\
\hline$\triangle \mathrm{LNCAP}$ & 0.139 & $\Delta$ LNGINI $_{(-2)}$ & 0.247 & $\Delta$ LNGDP $_{(-1)}$ & $-0.722 *$ \\
\hline$\triangle \mathrm{LNFDI}$ & 0.003 & $\triangle \mathrm{LNGDP}$ & -1.109 & $\Delta$ LNGDP $_{(-2)}$ & $0.869 * * *$ \\
\hline$\Delta \mathrm{LNHC}$ & 0.382 & $\Delta$ LNGDP $_{(-1)}$ & $2.034^{* *}$ & $\triangle$ LNENY & $0.638 * * *$ \\
\hline$\Delta \mathrm{LNTO}$ & 0.159 & $\Delta$ LNGDP $_{(-2)}$ & $-0.988 * *$ & $\Delta$ LNENY $_{(-1)}$ & -0.339 \\
\hline$\triangle \mathrm{LNFD}$ & -0.019 & $\Delta \mathrm{LNDI}$ & $-0.409 * *$ & $\triangle$ LNENY $_{(-2)}$ & $-0.361^{*}$ \\
\hline \multirow[t]{9}{*}{ ECT } & $-0.123 * * *$ & $\Delta \operatorname{LNDI}_{(-1)}$ & $0.810 * * *$ & $\triangle \mathrm{LNPOP}$ & $-0.022 * *$ \\
\hline & & $\Delta$ LNFDI & $0.046 * * *$ & $\triangle$ LNPOP $_{(-1)}$ & -0.017 \\
\hline & & $\Delta$ LNFDI $_{(-1)}$ & $-0.053^{* *}$ & $\Delta \mathrm{LNFDI}$ & 0.017 \\
\hline & & $\Delta \mathrm{LNTO}$ & 0.200 & $\Delta$ LNFDI $_{(-1)}$ & -0.001 \\
\hline & & $\Delta$ LNTO $_{(-1)}$ & -0.222 & $\Delta$ LNFDI $_{(-2)}$ & -0.03 \\
\hline & & $\Delta \mathrm{LNFD}$ & $-0.075^{*}$ & $\Delta \mathrm{LNTO}$ & 0.106 \\
\hline & & $\Delta$ LNFD $_{(-1)}$ & 0.044 & $\triangle L N F D$ & -0.015 \\
\hline & & $\Delta$ LNFD $_{(-2)}$ & $-0.079 * *$ & ECT & $-0.328 * * *$ \\
\hline & & ECT & $-0.585 * * *$ & & \\
\hline R square & 0.99 & R square & 0.89 & R square & 0.98 \\
\hline Ad.R square & 0.99 & Ad.R square & 0.89 & Ad.R square & 0.98 \\
\hline
\end{tabular}

Note: $1 . * * *, * *, *$ indicate significance at $1 \%, 5 \%$ and $10 \%$ levels, respectively. 2 . Ad refer to adjusted. 3. $\Delta$ is difference

In the case of South Korea (Table 4b), the short run elasticities (lag 0 ) for the model of growth shows that LAB has a positive impact on South Korea economic growth. Meanwhile, for the model of income distribution, the results show that there is a positive relationship between GDP, FDI, and GINI, while TO indicates a negative relationship. As for model of environmental quality, ENY is found to have a positive relationship with $\mathrm{CO}_{2}$ emissions while TO shows a negative relationship.

The highest speed of adjustment for South Korea follows a similar pattern as that of France, starting with the model of income distribution (-1.51), followed by a model of environmental quality (-0.66) and model of growth (-0.60). Approximately, 151\%, 66\% and 60\% disequilibria from the previous year's shock, respectively, converge back to the long run equilibrium in the current year. Moreover, the R-square values for all three models indicate a relatively good fit for the model. 
Table 4b: Estimation of Short Run Restricted Error Correction Model (ECM) (South Korea)

\begin{tabular}{|c|c|c|c|c|c|}
\hline \multicolumn{2}{|c|}{ Model of Economic Growth } & \multicolumn{2}{|c|}{ Model of Income Distribution } & \multicolumn{2}{|c|}{$\begin{array}{l}\text { Model of Environmental } \\
\text { Quality } \\
\mathrm{LNCO}_{2}\end{array}$} \\
\hline Variables & Coefficient & Variables & Coefficient & Variables & Coefficient \\
\hline$\triangle \mathrm{LNLAB}$ & $1.600 * * *$ & DLNGDP & $2.896 * * *$ & $\Delta \mathrm{LNCO}_{2(-1)}$ & 0.095 \\
\hline$\triangle \mathrm{LNCAP}$ & 0.027 & $\operatorname{DLNGDP}_{(-1)}$ & $2.398 * * *$ & $\Delta \mathrm{LNCO}_{2(-2)}$ & $-0.315 * * *$ \\
\hline$\triangle \mathrm{LNHC}$ & 0.230 & $\operatorname{DLNGDP}_{(-2)}$ & $2.029 * * *$ & $\Delta \mathrm{LNCO}_{2(-3)}$ & $-0.435 * * *$ \\
\hline$\triangle$ LNFDI & 0.003 & $\mathrm{D}\left(\mathrm{LNGDP}_{(-3)}\right.$ & $-0.852 * *$ & $\Delta \mathrm{LNGDP}$ & 0.103 \\
\hline$\Delta$ LNFDI $_{(-1)}$ & $-0.015^{*}$ & DLNDI & 0.211 & $\triangle$ LNENY & $0.896 * * *$ \\
\hline$\triangle \mathrm{LNTO}$ & -0.014 & $\operatorname{DLNDI}_{(-1)}$ & $2.053 * *$ & $\triangle \mathrm{LNPOP}$ & 0.045 \\
\hline$\triangle \mathrm{LNFD}$ & -0.063 & $\operatorname{DLNDI}_{(-2)}$ & 0.099 & $\triangle \mathrm{LNFDI}$ & 0.009 \\
\hline \multirow[t]{14}{*}{ ECT } & $-0.608 * * *$ & $\operatorname{DLNDI}_{(-3)}$ & 0.282 & $\triangle \mathrm{LNTO}$ & $-0.145^{*}$ \\
\hline & & DLNFDI & $0.488 * * *$ & $\triangle \mathrm{LNFD}$ & -0.045 \\
\hline & & $\operatorname{DLNFDI}_{(-1)}$ & $0.408 * *$ & ECT & $-0.661 * * *$ \\
\hline & & $\operatorname{DLNFDI}_{(-2)}$ & -0.198 & & \\
\hline & & $\operatorname{DLNFDI}_{(-3)}$ & $-1.069 * * *$ & & \\
\hline & & DLNFD & -0.019 & & \\
\hline & & $\operatorname{DLNFD}_{(-1)}$ & $0.575^{* *}$ & & \\
\hline & & $\operatorname{DLNFD}_{(-2)}$ & 0.260 & & \\
\hline & & $\operatorname{DLNFD}_{(-3)}$ & $-0.723 * *$ & & \\
\hline & & DLNTO) & $-0.611 * * *$ & & \\
\hline & & DLNTO $_{(-1)}$ & 0.152 & & \\
\hline & & DLNTO $_{(-2)}$ & -0.086 & & \\
\hline & & $\operatorname{DLNTO}_{(-3)}$ & $-0.497^{* *}$ & & \\
\hline & & ECT & $-1.514 * * *$ & & \\
\hline R square & 0.99 & R square & 0.81 & R square & 0.99 \\
\hline Ad.R square & 0.99 & Ad. $R$ square & 0.81 & Ad. $R$ square & 0.99 \\
\hline
\end{tabular}

Note: $1 . * * *, * *, *$ indicate significance at $1 \%, 5 \%$ and $10 \%$ levels. 2 . Ad refer to adjusted. $3 . \Delta$ is difference

\section{Conclusion and Policy Recommendation}

In summary, it is found that FDI inflows in South Korea have successfully led to a favourable impact on two out of three pillars of SD, which are higher economic growth, and lower pollution level. However, the impact of FDI inflows on income inequality is not favourable as more FDI inflows were found to lead to worsening income inequality. This may be due to higher FDI inflows being channeled to the service sector than to either agricultural or manufacturing sectors in South Korea. Thus, higher skilled jobs with better payments are found in the service sector compared to other sectors. The imbalance in terms of high skill jobs between the three sectors may create an income disparity in the society. This situation can be improved if the 
government could offer more attractive incentives to foreign investors to invest more in both agricultural and manufacturing sectors. More TO, on the other hand, has successfully improved the income distribution in the country but failed to have any significant relationship with growth and environmental quality. It is important for South Korean authorities to continue improving the TO policies in order to sustain economic growth. As for France, higher FDI inflows are found to increase economic growth as well as improving income distribution in the country. However, the relationship between FDI inflows and economic growth is found to be insignificant, just like its impact on environmental quality. In view of this finding, France should be more selective and only allow those foreign industries that use cleaner energy in their production of goods and services to operate in the country. Meanwhile, an increase in TO, not only does not promote economic growth but also leads to more environmental degradation. Thus, the French authorities should implement more stringent pro-environment policies and adopt stricter environmental strategies in their trade agreements with other countries in order to ensure better protection for the environment.

\section{References}

Abdouli, M., \& Hammami, S. (2016). Economic growth, FDI inflows and their impact on the environment: An empirical study of the MENA countries. Quality and Quantity, 50(216), 1-26.

Arora, R.U. (2012). Finance and inequality: A study of Indian states. Applied Economics, 44, 4527-4538.

Barro, R., \& Lee, J.W. (2011). Educational attainment dataset. Available at:<http://www.barrolee.com>

[Accessed 4 Jan 2016]

Belloumi, M. (2014). The relationship between trade, FDI and economic growth in Tunisia: An application of

the autoregressive distributed lag model. Economic Systems, 38(2), 269-287.

Canavire-Bacarreza, G., \& Rioja, F. (2009). Financial development and the distribution of income in Latin America and the Caribbean. Well-Being and Social Policy, 5, 1-18.

Çelik, S., \& Basdas, U. (2010). How does globalization affect income inequality? A panel data analysis. International Advances in Economic Research, 16(4), 358-370.

Cole, M.A., Rayner, A.J., \& Bates, J.M. (1997). The environmental Kuznets curve: An empirical analysis.

Environment and Development Economics, 2, 401-416.

$\mathrm{CO}_{2}$ time series 1990-2014 per region/country dataset, (2015). Emissions Database for Global Atmospheric 
Research [online]. Available at: http://edgar.jrc.ec.europa.eu/overview.php?v=CO2ts1990-2014 [Accessed 2 Jan 2016]

Frank, A.G. (1978). Dependent accumulation and underdevelopment. New York: Monthly Review Press.

Grossman, G.M., \& Kruger, A.B. (1995). Economic growth and the environment. Quarterly Journal of Economics, 110, 353-377.

Income Inequality dataset, (2015). Global Consumption and Income Project. [online] Available at:<http://gcip.info/graphs/download> [Accessed 12 February 2016].

International Labor dataset, (2015). International Labor Organization. [online] Available at:<http://www.ilo.org/global/statistics-and-databases/lang--en/index.htm>[Accessed 26 February 2016]

Klasra, M.A. (2011). Foreign direct investment, trade openness and economic growth in Pakistan and Turkey:

An investigation using bounds test. Quality and Quantity, 45, 223-231.

Krueger, A.O. (1978). Foreign trade regimes and economic development: Liberalization attempts and consequences. Lexington, MA: Ballinger Press.

Lee, W.J. (2013). The contribution of foreign direct investment to clean energy use, carbon emission and economic growth. Energy Policy, 55, 483-489.

Levine, R. (1997). Financial development and economic growth: Views and agenda. Journal of Economic

Literature, 35, 688-726.

Mah, J.S. (2003). A note on globalization and income distribution - The case of Korea. Journal of Asian Economics, 14(1), 161-168.

Mushtaq, M., Ahmad, K., Ahmed, S., \& Nadeem, M. (2014). Impact of FDI on income distribution in selected

SAARC countries. Journal of Applied Environmental and Biological Science, 4, 1-10.

Narayan, P.K. (2004). Reformulating critical values for the bound F- statistic: approach to cointegration: An

application to the tourism demand model for Fiji. Discussion Paper, Monash University, Australia 
Rostow, W.W. (1960). The stages of economic growth: A non-communistic manifesto. Cambridge University Press.

Sato, S., \& Fukushige, M. (2009). Globalization and economic inequality in the short and long run: The case of South Korea 1975 - 1995. Journal of Asian Economics, 20, 62-8.

Shahbaz, M. \& Rahman, M.M. (2010). Foreign capital inflows-growth nexus and role of domestic financial sector: An ARDL co-integration approach for Pakistan. Journal of Economic Research, 15, 207-31.

Shahbaz, M., Hye, Q.M.A., Tiwari, A. K., \& Leitão, N.C. (2013). Economic growth, energy consumption, financial development, international trade and $\mathrm{CO}_{2}$ emissions in Indonesia. Renewable and Sustainable Energy Reviews, 25, 109-121.

Stretesky, P.B., \& Lynch, M.J. (2008). A cross-national study of the association between per capita carbon dioxide emissions and exports to the United States. Journal of Social Science Resources, 38, 239-250.

Sylwester, K. (2005). Foreign direct investment, growth, and income inequality in less developed countries. International Review of Applied Economics, 19(3), 289-300.

Solarin, S.A., \& Shahbaz, M. (2015). Natural gas consumption and economic growth: The role of foreign direct

investment, capital formation and trade openness in Malaysia. Renewable Sustainable Energy Review, 42, 835-845.

Tamazian A., \& Rao, B.B. (2010). Do economic, financial and institutional developments matter for environmental degradation? Evidence from transitional economies. Energy Economics, 32, 137-45.

Wu, J.Y., \& Hsu, C.C. (2012). Foreign direct investment and income inequality: Does the relationship vary with absorptive capacity? Economic Modelling, 29(6), 2183-2189.

World Bank. (2016). World Development Indicators. [online] Available at: <http://databank.worldbank.org/data/download/archive/WDI_excel_2015_04.zip> [Accessed 2 April 2015].

World Commission on Environment and Development. (1987). Our Common Future (The Brundtland Report), Oxford University Press, Oxford. 
